$1-15-2020$

\title{
Keeping girls in schools to reduce child marriage in rural Bangladesh-Program brief
}

Population Council

Follow this and additional works at: https://knowledgecommons.popcouncil.org/departments_sbsr-pgy

Part of the Demography, Population, and Ecology Commons, Family, Life Course, and Society Commons, and the Gender Equity in Education Commons How does access to this work benefit you? Let us know!

\section{Recommended Citation}

"Keeping girls in schools to reduce child marriage in rural Bangladesh-Program brief." Dhaka: Population Council, 2020. 


\section{Keeping Girls in Schools to Reduce Child Marriage in Rural Bangladesh}

\section{CONTEXT}

Bangladesh has made considerable progress in improving access to education at all levels for last two decades. Despite these impressive gains, Bangladesh continues to face challenges of student drop-out at the secondary level. Girls drop out of school earlier than boys because of child marriage. Targeted policies and interventions designed to improve mainstream educational attainment and decrease child marriage may be the effective and sustainable way to address both issues.

\section{WHAT WE DO}

The Population Council, with UNICEF funding, implements an intervention research study to test a life-skills and tutoring support model to reduce school drop-outs among secondary-school girls and build aspirations for livelihood skills of unmarried girls who have dropped out of school with the goal of delaying marriage in Bangladesh. This project is part of UNICEF's "Education for Adolescents" and "UNFPA-UNICEF Global Programme to Accelerate Action to End Child Marriage". The Global Programme promotes the rights of adolescent girls to avert child marriage and pregnancy and enables them to achieve their aspirations through education and alternative pathways. The research study is intended to test for scaleup the success of BALIKA project ${ }^{2}$ https://www.popcouncil.org/research/ balika-bangladeshi-association-for-life-skills-income-and-knowledge-for-ado) in the intervention schools along with a control group to reduce school dropouts. more info visit: The study implications will be monitored systematically throughout the period for future scale up of intervention components. In the intervention schools, a blend of remedial educational support to in-school girls, soft skills-based livelihood training for out-of-school girls, strengthening school management committees (SMCs), community mobilization, and school improvement activities are being tested in contrast to the control groups where no interventions will be introduced.
More than one-third of students who complete primary school (40\%) do not complete the full cycle of secondary education

$\square$ Dropout rates from secondary school is higher for girls (46\%) compared to boys (34\%)

$\square$ Of girls who drop out, twothirds quit school due to marriage

(source: BANBEIS11)

\section{Goal}

Engaging

secondary schools

to promote skills

through after-

school activities to

keep girls in school

and reduce child

marriage. 


\section{WHO WE WORK WITH?}

The core project participants are adolescent girls aged 12-15 years living in rural Bangladesh. The project work with both in-school and out-of-school girls living in the communities. In-school girls are the weak students of class 7 and 8 who are at higher risk of drop out and thus subsequently for child marriage Group of in-school girls were selected based on their scores in the school examination and an assessment test before enrolment in the project. Out-of-school girls are selected from the community who reside within a two-kilometres radius of the intervention schools. Additionally, a group of educated local young women age between 20-25 years are actively involved with the project as Mentors.

\section{WHERE WE WORK?}

The Council, in consultation with UNICEF, selected three districts-Sherpur, Kushtia and Chapainawabganj-out of eight high child marriage districts identified by the "Education for Adolescents" program under the Ministry of Education and UNICEF. The project has randomly selected 48 schools, evenly divided between intervention and control.

\begin{tabular}{|c|c|c|c|}
\hline District & Upazila & $\begin{array}{l}\text { Intervention } \\
\text { Schools }\end{array}$ & $\begin{array}{l}\text { Control } \\
\text { Schools }\end{array}$ \\
\hline Sherpur & $\begin{array}{l}\text { Shreebordi, } \\
\text { Nalitabari }\end{array}$ & 8 & 5 \\
\hline Kushtia & $\begin{array}{l}\text { Bheramara, } \\
\text { Daulatpur }\end{array}$ & 7 & 9 \\
\hline $\begin{array}{l}\text { Chapai } \\
\text { nawabganj }\end{array}$ & $\begin{array}{l}\text { Chapai Sadar, } \\
\text { Shibgonj }\end{array}$ & 9 & 10 \\
\hline
\end{tabular}

\section{DURATION}

The project lasts 36 months, with three phases:

- Preparatory: 2018 Baseline, development of modules, monitoring framework, orientation of program managers and implementers.

- Intervention implementation: 2 years 2019-2020

- Evaluation and dissemination: March 2021

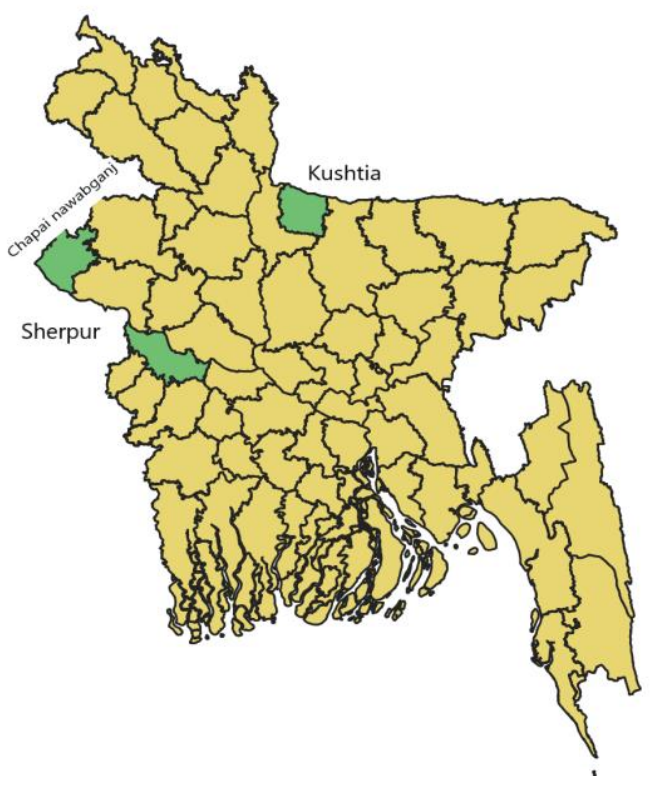

HOW WE WORK?

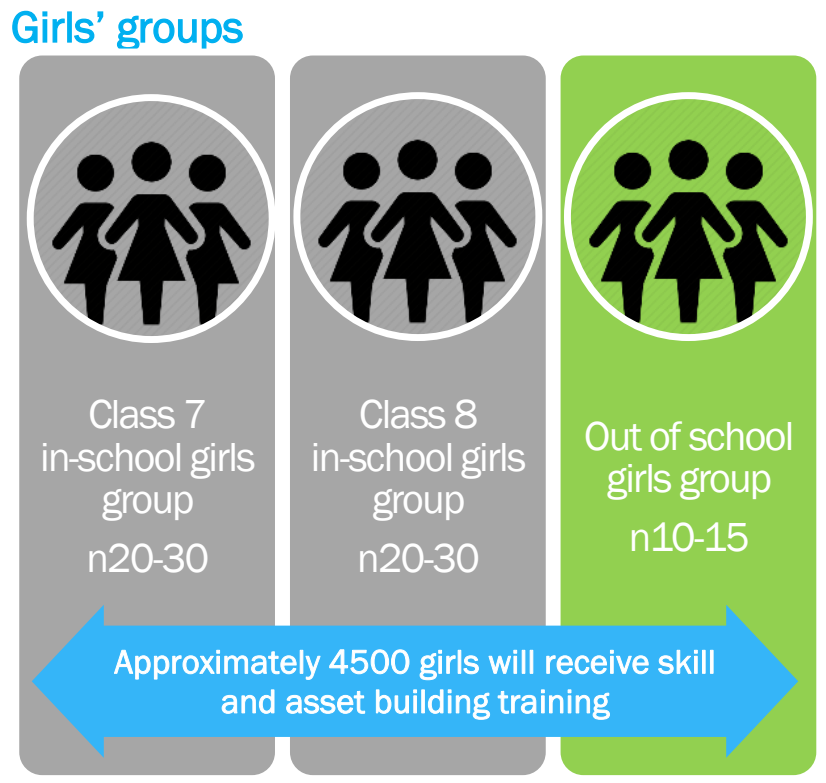

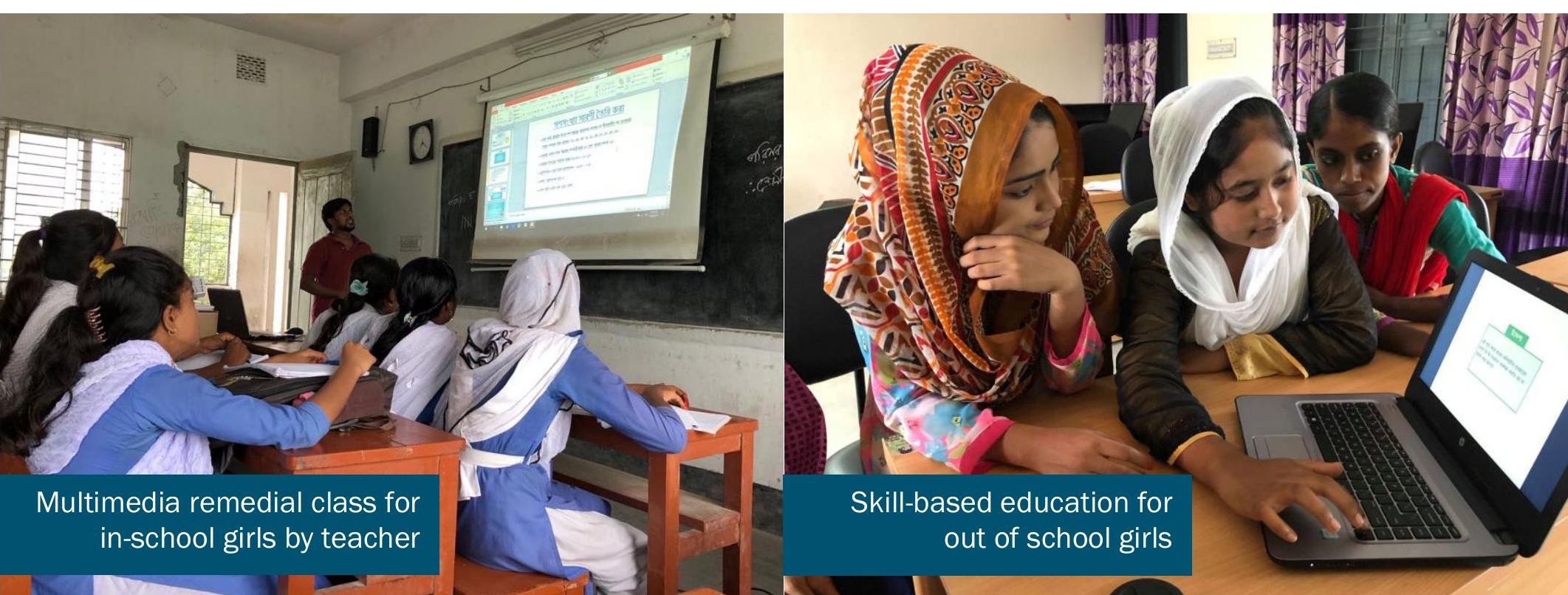




\section{Safe space}

Gathering in a safe space after regular school time twice a week is beneficial to adolescent girls in multiple ways. First, in-school girls are getting the benefit of remedial classes. Similarly, drop out girls are oriented with life skill-based education and livelihood training. Second, the program uses alternative pedagogy and new digital content and makes more use of online material than is used in regular school curriculum and emphasizes practical problem-solving skills through interactive learning processes.

Girls' receive 72-hour sessions in one year of intervention. Girls group meet twice in a week.

Third, girls are connected with Mentor-a young, empowered woman from their own community. As a role model for the girls, mentor holds sessions on multiple topics. The opportunity to get together regularly with mentors and other girls is expected to create lasting social assets and reduce social isolation, through peer networks and opportunities to share real life experiences. Moreover, mentors themselves are being able to improve their self-esteem and confidence that will contribute to formulate their carrier pathways in future. Regular interaction in safe space has positive influence on engagement in social activities outside the home and increase girls' participation in decision-making for both adolescent girls and mentors.

\section{Skill building interventions}

A structured curriculum of 72 hours (combination of Mathematics, English and Life skill-based education) are followed in the remedial classes for in-school girls. On the other hand, out-of-school girls receive training on life skills, Information and Communication Technology (ICT) and a range of health and financial topics. The modules on these topics were developed at the preparatory phase of the project. Financial literacy and soft skill-based livelihood training for out -of-school girls will create aspiration and provide a window of opportunity for entering vocational education or employment in future.

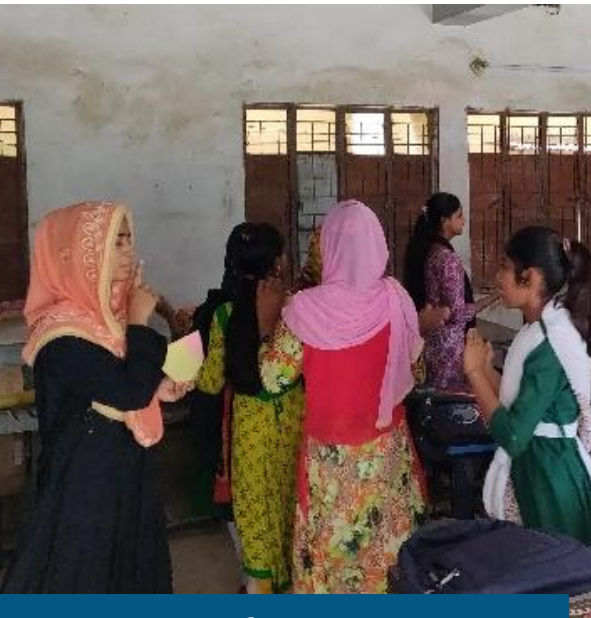

Mentor-led life skills sessions

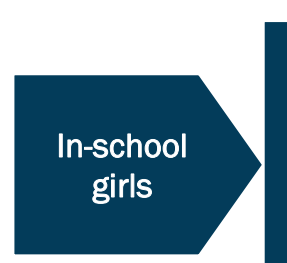

- Life skills and gender education by Mentor

- Need-based educational support for Mathematics \& English by subject teacher

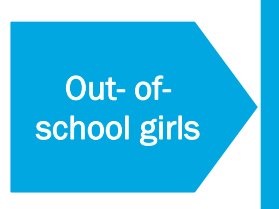

- Life skills and gender education by Mentor

- Livelihood trainings on ICT, financial literacy and basic health by Mentor.

\section{Mentors}

Young girls living in

the communities can

be a great resource to

lead and mentor other

adolescent girls in

their respective

community.
24 mentors engage girls in 24 intervention sites

Mentors are responsible for identifying and forming girls' groups and lead the life skills and livelihood training sessions with them. The age gap between mentor and adolescent girls are 5-10 years.

Mentors are young girls from the local community and living in the geographic area of intervention schools and currently studied in college or university. They are intended to work with the community for the improvement of lives of adolescent girls, have leadership quality to organize girls and work with girl's parents and school as well. Capacity development of mentors have been done through 13-day trainings at the beginning of the project and later on the job training and refresher training throughout the project period. Mentors receive a monthly stipend from the project. They have become a valuable resource for the local community in two ways-they potentially serve as role model for other adolescent girls of the community and can challenges social barriers and community norms which limit girls' mobility. Investments on mentor thus strengthen leadership among local girls and ensure a knowledgeable and responsive young advocate for other adolescents inside the community.

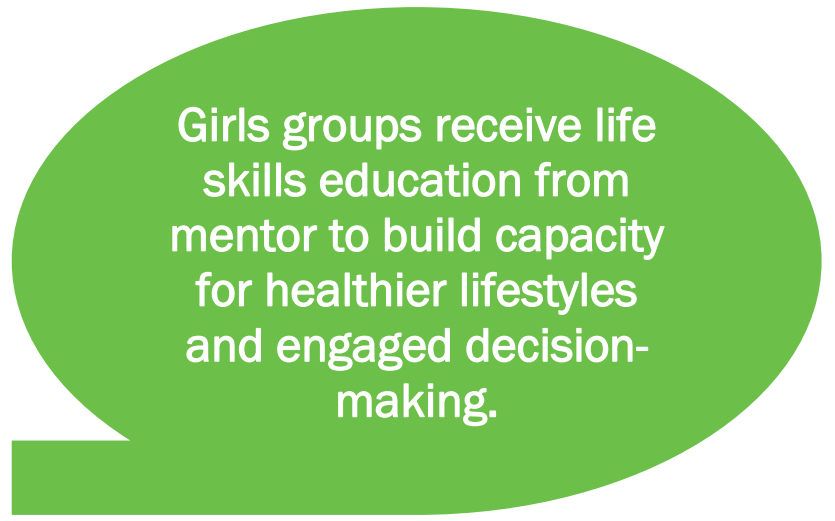




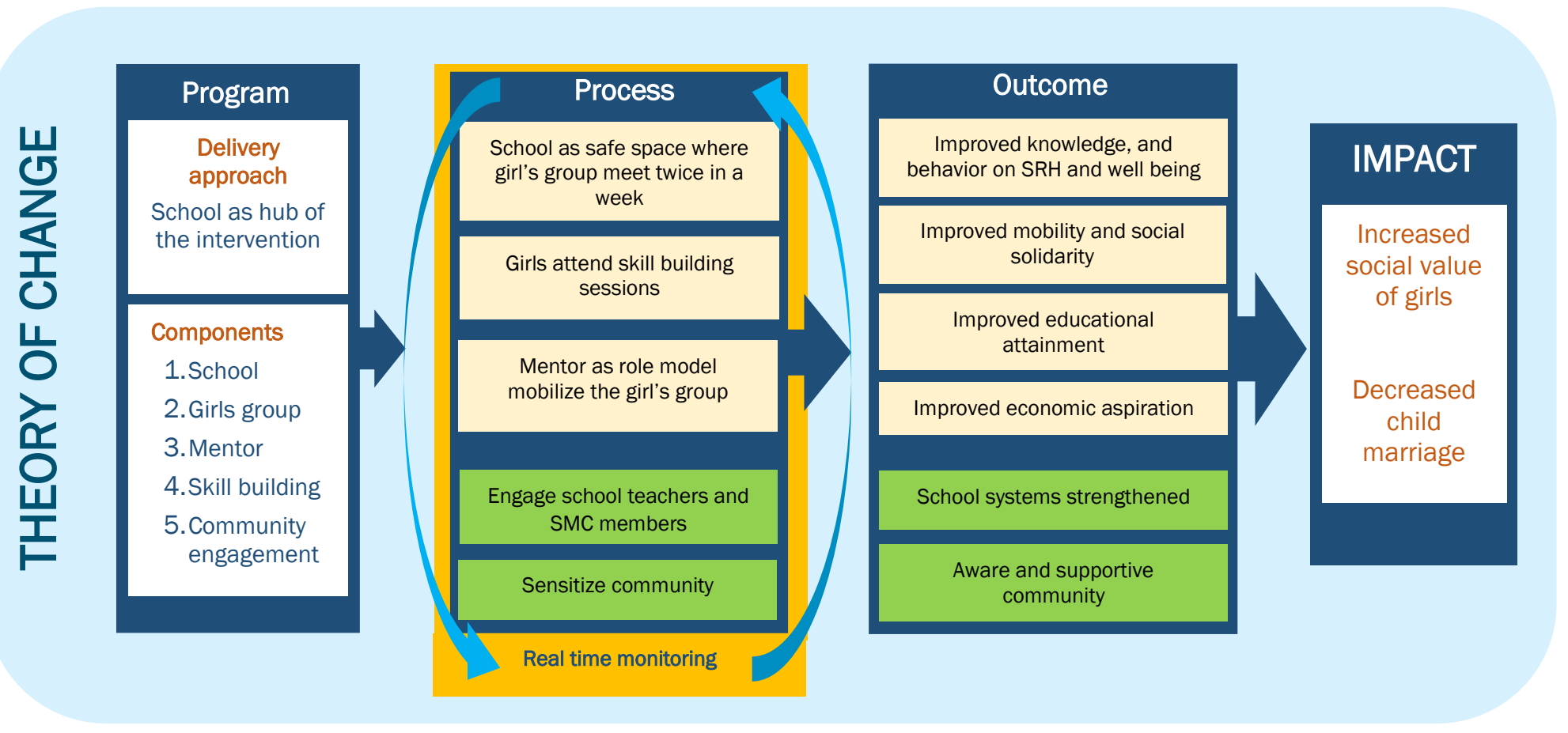

\section{Schools as intervention hubs}

Schools as a safe space are at the heart of the intervention. Schools capacity have been strengthened through providing physical resources, capacity building of teachers and mentors from the community. Each intervention school has been equipped with laptop, internet modem and multimedia projector to conduct after-school sessions with girls. Subject teachers received training on interactive and multimediabased teaching. Officials from Education department, local government representatives, SMC members, head teachers and subject teachers are engaged in preparing and implementation of the action plan and reviewing the progress quarterly.

\section{Program monitoring}

The Council developed a real-time online monitoring system to visualize data and to enable data reporting to multiple levels. Attendance status of the girls and quality of the sessions are monitored through SurveyCTO, a software based real-time online attendance and monitoring system. The system can demonstrate dashboards for all monitoring data which works as feedback loops for providing timely solutions (i.e., attendance, frequency of sessions, use of digital media etc.) of programmatic challenges in the study locations. Project staff, donor and implementers have open and equal access in the monitoring platform.

The Population Council conducts research and delivers solutions that improve lives around the world. Big ideas supported by evidence: It's our model for global change. popcouncil.org

\section{Community engagement}

To reduce child marriage and school dropout of girls, the project includes targeted activities to engage community members at different points of the intervention. One community sensitization meeting is organised at each school quarterly. A key objective of engaging community members is to create an enabling environment for implementing the activities to promote support from the community and diffuse opposition.

\section{SUSTAINABILITY}

The program strengthens existing relationships between school and community by engaging SMC members, parents, local stakeholders and teachers. The intervention will take over by the local actorsschool, SMC members, teachers, community people and mentor who will own and continue the intervention model after end of the project.

The project intends to establish "community fund' for long-term sustainability to provide operating costs after the project has ended.

To mobilize the community fund, community sensitization meetings will be organized with SMC, Upazila Parishad, Union Council and local stakeholders during the final year of the intervention.

\section{Reference}

1. Bangladesh Bureau of Educational Information and Statistics (BANBEIS). 2016. Bangladesh Education

2. Amin et al. 2018. Skills-building programs to reduce child marriage in Bangladesh: A randomized controlled trial. Published in Journal of Adolescent Health. 